zens Guide to Foreign Policy; Family Values; Income Inequality.

\section{References}

Harwood Group. 1993. College Students Talk Politics. Dayton: Kettering Foundation.

Morse, Suzanne. 1989. Renewing Civic Capacity: Preparing College Students for Senvice and Citizenship. Washington, DC: ASHE-ERIC Higher Education Report No. 8.

Murchland, Bernard. 1991. Higher Educa tion and the Practice of Democratic Politics. Dayton: Kettering Foundation.

McKenzie, Robert. 1994. Public Politics. Kansas: Kendall/Hunt.
Daniel W. O'Connell is a member of the Florida Bar. He teaches political science at Palm Beach Community College in Lake Worth, Florida, and is a visiting associate professor at the Kettering Foundation (1994-95).

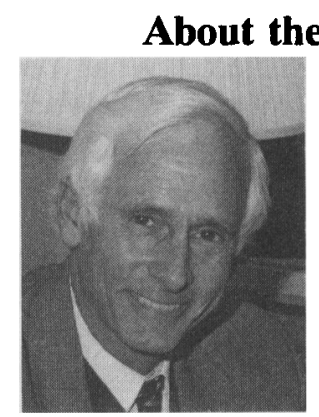

Robert H. McKenzie is an associate professor in New College at The University of Alabama at Tuscaloosa. $\mathrm{He}$ teaches in the areas of civic effectiveness, public policy, and public leadership. $\mathrm{He}$ is author of Public Politics, Kendall-Hunt Publishing Co., 1994.

\title{
A Comparison of Washington Semesters at Public Colleges and Universities: Who Gets What, When and How
}

\author{
William D. Pederson, Louisiana State University-Shreveport \\ Norman W. Provizer, Metropolitan State College
}

There is a "revolution" in learning that is taking place in America. It is a silent revolution in academia, a movement begun in and out of Washington, D.C. that has spread over the past sixty years, nurtured by modern political scientists devoted to teaching. The Washington Semester, as this movement may be called, has brought experiential education to countless college and university students, adding a new dimension to civic and cultural education in America. The ripple of influence of this political science movement has touched Main Street and mainstream politics as evidenced by the fact that the 1980 Democratic presidential candidate was a product of this "revolution" (Navasky 1988). An unstructured network of Washington Semesters involving several hundred colleges and universities from some fifty independent programs and others affiliated with private organizations, the Washington Semester experience remains the best kept secret in innovative American civic education. The diversity of such a pervasive movement invites analysis and comparison to identify com- monalities and differences of these programs at public institutions.

For purposes of analysis, this paper is divided into three sections: (1) a "methodological" discussion defining "Washington Semesters" and a presentation of their evolutions; (2) three case studies, chosen randomly, ranging from the South (LSU in Shreveport), to the West (Metropolitan State College) to the Midwest (University of MichiganDearborn), and (3) some tentative conclusions about the "Washington Semester" for less affluent public college and university students.

\section{A "Revolution" in Civic and Cultural Education}

Although some 20 million people, including several thousand college interns, visit Washington, D.C. annually, Washington programs that emphasize both civic and cultural components are a vastly unrecognized species. In part this may be because internships are now a Washington institution, popularized in the media and in the political science profession (Frantzich 1991).
Most colleges and universities offer internship programs of some kind. Unfortunately, standard reference works make no effort to distinguish whether they are (1) offered in Washington, D.C., (2) "independent study" courses which students pursue on their own, (3) independent programs or if they are affiliated with another institution. The frustration created by lack of information gave rise to a nearly decade-long effort to compile a directory of Washington programs for college and university students. ${ }^{1}$

As this overview suggests, the very definition of a Washington Semester is imprecise. It has evolved into an amorphous program including a range of approaches from tour groups (a vacation) to traditional internships. This is doubly unfortunate, for tour groups represent pure vacation without formal education while internships are often unstructured and may represent a privilege for students who are able to buy into the Washington power market.

Washington Semesters are annual group programs for college and university students, containing both 
internship and non-internship academic dimensions, directed by a faculty member in Washington, D.C. Within this definition exists a continuum of possibilities related to timing (duration and regularity), admission requirements, credit hours, sponsors, and similar structural details.

The preliminary data on these programs show that the first Washington Semester was started in 1935 by the late Paul Jacobsen, a political scientist at Colgate University in New York. American University established its Washington Semester in 1947. It continues to actively recruit students, as well as colleges and university associations with its program, and deserves mention for being the first school to popularize the notion of a Washington component in the curriculum for college and university students. Quantum leaps in expanding Washington programs to several hundred colleges and universities occurred with the establishment of the Washington Center in 1975, and the more recent Institute for Experiential Learning in Washington, D.C. Coinciding with the formation of these private organizations and others working with colleges and universities to arrange programs in Washington, D.C. was the emergence of branch campuses in the nation's capital. ${ }^{2}$

Another, more subtle pattern developed during the same period: gan offering Washington programs for their constituents. It is this trend that merits closer scrutiny in this paper. Three of eight public institutions currently offering Washington Semester programs have been selected for analysis and public colleges and universities be-

comparison. Each has addressed the issue of offering Washington Semester programs for their students who lacked the advantage of attending a college or university in the Washington area or who lacked the funds to take advantage of such programs offered by private organizations.

\section{The South}

The first university in the South to offer an independent Washington Semester was Louisiana State University in Shreveport. The program was initiated with the assistance of a grant from a local family which stipulated creation of a larger American Studies program. Hindsight suggests that it would have been prudent to have segmented the Washington Semester from the other year-round program components. The first director of the American Studies program and the Washington Semester was a political scientist who was afforded only one-quarter time to direct both programs, while teaching three courses per semester (Aiello 1990, Fritze 1994).

The founding director had served in the 1970 s at the U.S. Department of State and the National Institutes of Health while in graduate school. His self-directed experiential education was central to the subsequent decision to establish an independent program available to LSUS students for the lowest price possible. The annual program has operated for more than a decade under the same basic procedure, with one notable change. The university now pays the director's entire summer-equivalent salary,

\begin{tabular}{llcl}
\multicolumn{3}{l}{ Independent Washington Semesters at Public Colleges and Universities } \\
\hline \multicolumn{1}{c}{ Institution } & State & $\begin{array}{c}\text { Date } \\
\text { Established }\end{array}$ & Founding Director \\
\hline SUNY at Brockport & NY & 1968 & Michael R. Weaver \\
Indiana University-Kokomo & IN & 1972 & Allen B. Maxwell \\
Kent State University & OH & 1972 & Mary S. Bacon \\
University of Michigan-Dearborn & MI & 1977 & Helen M. Graves \\
LSU in Shreveport & LA & 1982 & William D. Pederson \\
Salisbury State University & MD & 1988 & Harry Basehart \\
Metropolitan State College & CO & 1991 & Norman W. Provizer \\
Shepherd College & WV & 1991 & \\
\hline
\end{tabular}

rather than the former one-third university, two-thirds grant funding arrangement.

To keep costs down, the Washington Semester was offered between the end of the spring term and the beginning of the regular summer term, a period of three weeks (four weeks for interns). The result is an intensive, compressed program that begins at 6:00 a.m. and continues beyond midnight seven days a week.

It consists of two components: (1) the regular internship of forty hours a week in a governmental office, and (2) a cultural course component. Students may earn up to six academic hours by a combination of participation in these experiential activities, completing required academic assignments that include a short paper written before the program begins, a daily journal, a term paper, a second short paper, and required readings.

This full academic load is supervised by a faculty member living in the same dorm as the students while in D.C. By the end of three weeks, students generally have assimilated into the Washington scene and no longer feel like tourists. About twenty-five percent choose to participate in the Washington Semester for a second term, selecting the complementary component of the program. Groups average two dozen participants.

\section{The West}

In 1990, the LSU in Shreveport Washington Semester produced an offshoot when a faculty member in political science moved from that university of 4,000 students to Metropolitan State College in Denver-an urban, undergraduate state institution with more than 17,000 students.

Impressed by the programs developed at LSU in Shreveport, the faculty member approached the chair of the political science department at Metropolitan State about the possibility of establishing a similar summer session. His advocacy stressed that students at smallname (if not small-size) state institutions should have available to 
them as many educational options as possible. Who gets what, in this regard, should not reflect the kind of simple hierarchies and rankings found in higher education as well as other aspects of life. A publication promoting private colleges and universities, for example, notes that while such institutions contain only twenty-one percent of all enrolled students, they have produced twenty of the thirty-one presidents of the United States who possessed a college degree, forty-six of the one-hundred current members of the Senate, and one hundred eighty-nine of the sitting members of the U.S. House of Representatives. ${ }^{3}$ Certainly, it does not denigrate such statistics for a public institution to view them as a standard, a challenge-and as a reason to expand student horizons, rather than shy away from programs like the Washington Semester.

For a public institution such as Metropolitan State College with a large number of nontraditional, older students, there was another consideration. Should older students be precluded from participation in such programs because of "when" (that is, at what age) they entered the higher education process? In short, this variant of the justice-as-fairness argument seemed to have compelling aspects. The administration agreed to implement a Washington program.

Unlike LSUS, there was no philanthropic grant to underwrite program costs, so to avoid even the slightest hint of added, indirect costs, the decision was made to structure the summer program around existing courses in political science rather than to structure new classes around the program as had been partially the case in Shreveport. The basic Washington Semester package would consist of two three-credit courses in these areas, with alternate internship credit available for those students selecting that path in Washington.

In establishing the focus for its program, the Denver college emulated the LSUS model. While the LSU in Shreveport program was generated under an American Studies label and offered lower as well as upper-division options, its core principles remained valid for adaptation by Metropolitan State. The primary goal of both programs was to expose students to America's national political legacy. The major structural addition to the adapted plan came in the form of a concerted effort to supplement daily activities with direct meetings that went beyond mere personal visits to congressional offices.

Thus, what emerged was a program with six Washington elements: exposing students to the basic symbols of Washington; exploring the city of Washington; discovering historic sites off the tourist path; taking advantage of talks at diverse public and private institutions, as well as various exhibits; discussing issues in small, personal forums with knowledgeable individuals representing different facets of Washington's political culture; integrating all of the above components with relevant and informal discussions of the aspects of the American political process and its structures, as well as readings on such subjects. Additionally, students would write papers upon their return to Denver, reflecting upon and linking together their experiences and their required readings. In reality, the time in Washington would be combined with the remainder of the summer session back home.

Like LSUS, Metropolitan State planned to use dorms at The George Washington University. However, a new minimum stay requirement of four weeks, which did not apply to programs that had used the dorms in the past, was imposed necessitating the Denver program to lengthen its time in Washington. That decision produced both positive and negative results.

The expanded time frame reinforced the in-depth nature of the program-and its flexibility. The disadvantage was that the longer schedule limited participation, especially at a college heavily populated by nontraditional students who face many real-life responsibilities. Since it was launched in the summer of 1991, the average enrollment has been 11 students.

Initially, the Dean's office agreed to fund salaries for three-credit hours beyond the department's normal summer allocation and also agreed to pay for expenses of the faculty member directing the program. By its second year, the extra allocation was withdrawn, requiring the ongoing program to be absorbed into the departmental budget.

\section{The Midwest}

Older than the two previously discussed programs and perhaps the best kept secret among Washington Semesters is the well-established program at the University of Michigan at Dearborn, also a public institution. Political scientist Helen M. Graves began it in 1977 as a summer internship and seminar program. ${ }^{4}$ Each year the program averages about fifteen participants who are housed in a dorm at Georgetown University. The program differs from LSUS and Metro State in its length. Almost twice as long, it spans seven weeks in June and July.

Unlike the Shreveport and Denver programs, the Dearborn Washington Semesters include international students. The director began in 1988 accepting university students from Ontario, Canada, including Carleton University, the University of Ottawa, and Queens University in Kingston. It is the only Washington Semester with a Canadian dimension to it, and it has the most international participants. A study of the program requirements, its outcomes and the impact of international students upon the American participants is necessary before meaningful comparisons and conclusions of this aspect of the Dearborn program can be made.

In addition to serving in a variety of internships, attending seminars with outside speakers, participating in tours and other group gatherings, the participants meet requirements much like those of the Denver and Shreveport programs. They write "focused journals," conduct interviews with political figures, and write a ten-page paper. There is on-site supervision from the program director. In exchange for acceptable completion of this academic work, students earn six 
hours of upper division political science credit.

A significant difference between the Dearborn program and the other two described is financial. The monies collected from the participants in the Dearborn program are used to offset student tuition and housing as well as the salary of the director and all other administrative costs of the program. For the LSUS and Metropolitan State programs, which benefit from institutional support, the more established University of Michigan at Dearborn Washington Semester offers a model of self-sufficiency.

\section{Some Tentative Conclusions}

An analysis of the three case studies discussed in this paper suggest some tentative conclusions about who gets what, when, and how during Washington Semesters. The paper also suggests some of the options available to public college students and faculty contemplating participation in a similar program, starting one, or expanding an already existing program.

First, the three case studies show that public colleges and universities can participate meaningfully and successfully in the Washington Semester movement. Washington Semesters may have originated in private institutions and been popularized by institutions in or close to the Washington area, but remote public institutions such as those examined in these case studies also have made contributions.

Second, costs influence not only duration of the program and its tuition, but also challenge the resourcefulness and imagination of faculty and administrators. Creative innovations are possible for those who desire to overcome tuition differentials between private and public institutions.

Third, though these programs are abbreviated in comparison to programs lasting a regular semester, they demonstrate that the three-toseven week program may uphold academic standards when directly supervised by an on-site faculty member.

Finally, the paper suggests a continuing active role for political scientists who began the Washington Semester movement, popularized it, then extended it to public institutions. The internship and experiential programs remain higher education's best kept secret in innovative civic and cultural education. They offer political scientists the challenge of elevating public awareness of the role of the Washington Semester within the American political consciousness. It was, after all, in Federalist No. 85 that Alexander Hamilton approvingly cited David Hume's view, "The judgements of many must unite in the work; EXPERIENCE must guide their labour . . ." (Rossiter 1961, 526-27). In Donald Lutz's words, that idea " . . . serves as a succinct introduction to the most fundamental aspect of both Federalist and Antifederalist thought, namely, the conviction that as useful as books can be, politics should always rest upon a base of human experience rather than upon logical abstraction ..."' (Lutz 1992, 115). Time has not diminished the meaning of that message and endorsement of the purpose that motivates all Washington Semesters.

\section{Notes}

1. William D. Pederson and Norman W. Provizer, A Directory of Washington Programs for College and University Students, forthcoming. The authors would appreciate information on any Washington Semester programs to insure inclusion in this work.

2. "Universities are Setting Up Branch Campuses in Capital," New York Times, November 22, 1989, p. 23.

3. Private Colleges and Universities,
1994. Publication of Carnegie Communications, 43.

4. Our appreciation to Dr. Helen Graves, as well as the directors of the other programs for sharing information about their programs with us.

\section{References}

Aiello, Dennise. 1990. "LSUS Washington Weeks.” Shreveport Journal. 27 June.

Frantzich, Stephen E. 1991. Storming Washington. An Intern's Guide to National Government. 3rd ed. Washington, DC: American Political Science Association.

Fritze, James N. 1994. "LSUS Could Make You a Washington Insider." The Times (Shreveport, LA) 14 July.

Lutz, Donald. 1992. A Preface to American Political Theory. Lawrence: University Press of Kansas.

Navaksy, Victor. 1988. "Big Mike on Campus.” Esquire 110:130-42.

Rossiter, Clinton, ed. 1961. The Federalist. New York: Mentor Books.

\section{About the Authors}

William D. Pederson

is a professor of political science at Louisiana State University in Shreveport. His most recent books are Abraham Lincoln: Sources and Style of Leadership (1994) and Abraham Lincoln: Contemporary (1995). Since 1992, he has coordinated an international and multidisciplinary presidential conference series.

Norman W. Provizer is a professor and chair of the department of political science at Metropolitan State College of Denver. $\mathrm{He}$ is the coeditor of Grassroots Constitutionalism (1987) and Great Justices of the U.S. Supreme Court (2nd ed., 1994), and also serves as the Director of the Golda Meir Center for Political Leadership at Metropolitan State College. 